\title{
Symbolic characters and class struggles in Ngugi's wa Thiongo's Petals of Blood
}

\section{Stanley Ordu}

Chaps, Omoku in Rivers of Nigeria, Nigeria

stanleyordu12@gmail.com

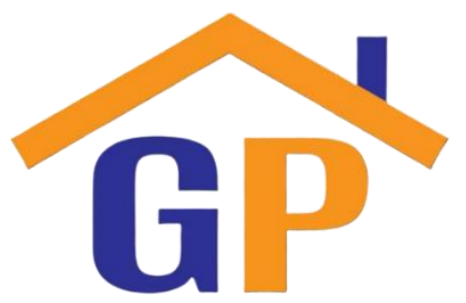

\begin{abstract}
Purpose: Every piece of art must, without a doubt, make a statement about itself. This is due to the fact that the more attractive something is, the more symbolic it becomes. Almost all works of art have multiple interpretations. Every great work of literature contains symbols, which add depth, meaning, strength, and dexterity to the work.
\end{abstract}

Research methodology: Two theoretical frameworks, postcolonial and Marxist literary theories, guided the analysis. And this is a qualitative study.

\section{Article History}

Received on 10 September 2021

$1^{\text {st }}$ Revision on 15 September 2021

$2^{\text {nd }}$ Revision on 7 October 2021

$3^{\text {rd }}$ Revision on 13 October 2021

$4^{\text {th }}$ Revision on 19 October 2021

$5^{\text {th }}$ Revision on 26 October 2021

$6^{\text {th }}$ Revision on 29 November 2021

Accepted on 7 December 2021
Results: The results of this investigation demonstrate that colonial injustice and unmodified colonial institutions and policies are the most enduring issue of Ngugi Wa Thiong'o's literary exploitation.

Limitations: The study is limited to one novel and which is Petals of Blood of Ngugi Wa Thiong'o, written after the postindependence of Kenya.

Contribution: Finally, the study found that people are aware of their rulers' actions and are plotting a revolt to break free from the elite's grasp. And it proposes viable answers to their political and socioeconomic problems, such as revolution, not just in Kenya but throughout Africa.

Keywords: African leaders, Marxism, Personalities, Post-colonial, Symbolism

How to cite: Ordu, S. (2022). Symbolic characters and class struggles in Ngugi's wa Thiongo's Petals of Blood. Journal of Social, Humanity, and Education, 2(2), 129-139.

\section{Introduction}

A work of art should be able to stand on its own. However, the more successful a work of art is, the more symbolic it becomes; each piece of art necessarily has several meanings. All of the literature's great works have been metaphorical, and as a result, they have grown in complexity, power, depth, and beauty. The goal of this research was to evaluate and analyze Ngugi was Thiong'o's portrayal of neocolonial Kenya and his attempt to reform that corrupt society through the employment of characters who reflect these faults and this also aimed to demonstrate how Ngugi wa Thiong'o uses literature (symbolic characters) as a means of communication and expression to open people's minds and aid in the liberation of oppressed people by demonstrating his commitment to the fight against neocolonialism and capitalism (Aidoo, 2007).

Ngugi's Petals of Blood was examined as an invitation to the masses and working-class organizations to take action against the new governing elite's mistreatment of them. The novel Petals of Blood is reviewed to see how Ngugi writes it to condemn colonial rule and neocolonial exploitation of Kenyans. Another point of importance is that Ngugi's literary works are consistent with the Holy Bible. His compositions bear some resemblance to biblical events. Ngugi, for example, recalls an incident in Matigari in which Matigari sneaks out of prison unobserved among the heavy police patrols. Similarly, an unknown individual unlocks the jail doors where Paul and Peter are being held, allowing them to go unnoticed under the severe protection of Roman troops. As a result, reading his books became necessary for the scholar to discover the relationship between Ngugi's fictional work and the biblical background. 
Petals of Blood is notable for its depiction of human conflicts. The novel shows how the exploited might win these human conflicts and put an end to exploitation. At the end of the Petals of Blood, death signifies a shift in power dynamics, as the leaders who prefer to associate with the masses' dominance are suppressed and oppressed. Ngugi employs the protagonist's assassination of the elite's leaders to eliminate them once they have realized their suffering. This work has demonstrated how works of fiction can change people's thinking and how people can react to that change to cease the human struggle caused by the new governing elite's mistreatment.

\section{Literature review and hypothesis development}

This study aimed to review the literature on symbolic characters, their implications in neocolonial Kenya, and class struggles. The goal was to check some of the previous research papers in the study and to see if this study may add new knowledge by building connections and relationships with current material. Studies and research that have already been done on symbolic characters provide helpful information that can be referred to in the future. This study, which situates Kenya within the context of Kenyan neocolonialism, aims to go beyond existing knowledge by delving deeper into the challenges that have plagued Kenya since independence while also demonstrating how Ngugi provides an escape from such issues. By way of his literary works. However, the scope of this research is limited, and it takes a specific approach. The work's metaphorical characters are examined and their class struggles.

However, in Petals of Blood, Karega stops marrying Mukami, his love, because he hails from an impoverished family. As a result, Mukami kills herself. Karega is befuddled, heartbroken, and rejected as a result of his girlfriend's death. What happens to Karega exemplifies or symbolizes the spirit of class difference and the elite's lack of acceptance of the masses; for them, wealth is more important than a decent existence. Karega suffers at the hands of his future father-in-law simply because he, Karega, does not have the same social standing as his future father-in-law. (Mushengezi, 2003) describes the people's predicament as sorrow, isolation, loneliness, and denial. They appear to live in a separate world from the elite, yet they do. This view is echoed by the disparities in the locations of the masses and the elite in modern Ilmorog. The new Ilmorog between the rich, who make up the ruling class, and the poor, who make up the masses, has been revealed as dehumanizing, with the rich's rubbish deposited in the poors' dwelling quarters (Wa Thiong'o, 1982). The more reason (Mushengezi, 2003) advocates for a change of the capitalist economic system and its downfall as the sole solution to the African masses' deplorable living conditions. (Eagleton 2013) criticizes the groups for maintaining capitalism on "life support" by agreeing to exploit the elite through overworking and providing cheap labour to the governing elite. Invariably, where there is no exploitation and freedom, there must always be the improvement of life and production. (Mahammad and Seyed, 2021).

New elites have learned to manipulate the masses to pay for their crisis of acceptance of a money system that they have failed to implement in this way. However, (Herbst, 2000) promises the masses that triumph is on their side if they work together and persevere in their fight until they win. In support of the view that the groups are struggling, it can be claimed that, while the governing elite appears to live comfortably at the expense of the lower class, Herbst envisions a new world forming as a result of exploited class strikes and demonstrations (Amuta, 1986). Independence appears to be in vain for the majority because they still lack fundamental amenities such as land tenure, clean water, and decent shelter.

According to Wa Thiong'o (2009), Kenya's economy favours the imperial power and its associated dominating groups. In this regard, it is noted that factories and businesses are still owned by Kenya's bourgeoisie in collaboration with foreigners (Amuta,1989). Ngugi criticizes the new leaders, who continue to exhibit the same social prejudice as the colonizers and pursue the same economic arrangements (Amuzu, 2004). He wants Kenyans to control and own the country's resources. The masses, who had hoped for a better life after independence for so long, remain impoverished. Karega, the protagonist, depicts a poverty-stricken scenario in which he has no place to call home. He's been observed squatting with buddies in Ilmorog since his father died. That is why, according to (Fashina, 2009), if the masses wish to break free from oppression, they must be organized and established and combat exploitation without fear. He believes that if the oppressive chain is broken, power and riches 
will flow freely from the exploiters to the rest of the country (Bardolphe,1987). Ngugi sees Kenya as a country riven by class conflict, anguish, poverty, and dehumanization. Ngugi demonstrates the existence of related situations among the masses in Matigari and how the masses react to them in Matigari. Matigari confronts the cops about an inhumane deed they perpetrated against Gutherie and manages to prevent the dog from biting her (Wa, Thiong'o, 1989). The cops threaten to arrest him, but he is stopped by his magical ability when "he grows into a giant, and his voice roars like an earthquake and shakes the ground where they are standing" (Wa, Thiong'o, 1989). Matigari begins his hunt for justice and truth in every part of Nairobi, but he is detained for vagrancy (Kubayanda, 2013).

Observes that the anarchy brought on by Africa's new ruling elite is a "betrayal of principles and trust that is too much to excuse" (p. 29). In other words, he considers the exploitation of peasants and workers in most African countries to be a challenging position to reverse (Bahbah,2004). Jomo Kenyatta was the first black Kenyan president to lead postcolonial Kenya. However, according to (Wa, Thiong'o 1986), Kenyatta was still troubled by grudges against other Kenyans. As a result, he failed to keep the promises he made during the liberation struggle even after independence. Instead, Kenyatta created new leadership structures that reflected his own goals rather than those of the people he was guiding. $\mathrm{He}$ also kept many skilled whites in high-ranking positions in the court and civil service and sees Kenyatta's regime as the start of neocolonial Kenya's suffering, even though, from the beginning, Jomo Kenyatta echoed the aspirations and yearnings of Kenyans during the Mau Mau war when he promised them changes that would occur during his reign; he said: Our march to freedom has been long and arduous. There have been times when all we had was a passionate belief in the rightness of our cause to keep us going Achebe, C. (1985). Things Fall Apart. Harare, Zimbabwe: Zimbabwe Publishing House. Love Story. London, UK: Oxford University Press. The tragedies and misunderstandings of the past are no longer relevant. Today, we begin the arduous task of establishing Kenya as a nation. Kenyatta, p. 212. As a result, the promised socio-political atmosphere never materialized, and Kenyans continued to suffer and endure tragedy. Leadership has a great deal of attention in every facet of life, and great and good leadership brings globalization and technological advancement to the masses (Godson, 2021).

A period of disenchantment throughout his rule In truth, most Kenyan peasants still live in poverty, despite the country's hard-won independence (Killam, 1984). The housing conditions of the general public in metropolitan regions are deplorable. Ngugi reveals this photo in Matigari (1989), where the lads "dwell in a scrapyard" (p.16). A privileged minority controls the riches, which surrounds itself with "mansions, costly automobiles, television sets, and all the consumer durables associated with an acquisitive affluent class" (Wa Thiong'o, 1977). (Wa Thiong'o, 1977) and (Killam, 1980) forecasts that the poor will remain poor while the wealthy gain richer until change occurs. In Petals of Blood, Karega's mother has spent her life working tirelessly and faithfully on the wealthy elite's farms and plantations. Yet, she dies without anything, not even a piece of land from her employers. Another example may be seen in (Matigari 1989), where "some small boys rush to wait so that they might enter the rubbish site to hunt for food and clothes" (Wa Thiong'o, 1989).

These lads reside in a scrapyard, representing the living conditions of the impoverished in Nairobi who cannot afford a permanent home. Ngugi's description of the boys' clothing, "wearing ragged clothes full of patches of different colours of the rainbow" (Wa Thiong'o, 1989), denotes that they belong in the shanty settlements. Residents of shantytowns and trench dwellers are referred to as "the wretched of the earth" (Fanon 1990). According to Fanon, the peasants' wretched habitation is marked by the death of infrastructures, broken-down shanties, and a disorganized pattern of settlements, filth, and miserable existence. People who have endured in the liberation fight are still suffering in the land they have already fought for and liberated, Ngugi lingers on the heinous specifics of the masses' locations. The independence fighters are jobless and live in squatter camps. Abdulla's condition exemplifies the unemployment of ex-freedom soldiers. He is unable to obtain work and is derided as a handicap when attempting to do so. "To live in such climate of indifference, psychological upheaval is like paranoia, recidivism, kleptomania, and everywhere the peasant turns to he confronts class hate, rejection, discord, and fear," writes (Mwaura, 2005), echoing Abdulla's position (Mwaura, 2005). (Eagleton 2013) believes that the war of class division and struggle on the African continent would worsen than 
it was at the start due to an increase in the suffering of the people in the twenty-first century as he posits: Class division is in our reality because of the capitalist's economic system beyond and within our continent. This system affects all people in different ways. Because of the continuous suffering in the African countries, there arose a spirit that vindicates revolution as the only process that can bring the real Africa back. So there was a revolution in Egypt, a what we learn from it is that other countries may follow (Eagleton, 2013).

As a result, the plot structures of the stories in this novel mirror the trials and tribulations of Kenyan peasant life (Kurtz, 1998). Besides that according to (Kurtz 1998) that these ordeals of misery are proof enough that there is suffering in the world today and that the only remedy is constant revolution, as people in the Arab world have demonstrated.

The people appear to have been let down by those in positions of power. Ngugi can capture events in both rural and urban areas to provide a unique perspective and complete picture of the people's predicament. The fate of the city dwellers, individuals, job seekers, and those with lower social status in neocolonial Kenya are freely accessible.

They can be identified by how they dress, eat, or travel. For instance, suppose a lady passes out when she meets Munira at a social gathering with his uncombed hair and crumpled, muddy, soiled clothes. She has gathered many representatives from diverse communities because she cannot bear to watch such a humble creature (Wa Thiong'o, 1977).

Another event has occurred in Matigari, where the boys have abandoned their homes. Parents who have moved to the city in pursuit of a better life yet are nonetheless unemployed. The boys compete in a race against the clock. Tractor to the waste dump, where people line up to go inside since it's the only way they know to survive the metropolis (Wa Thiong'o 1989). Ngugi focuses on unemployment since it is one of the most difficult challenges he faces. One of the significant hurdles to development in Kenya is the youth. Africa has many countries. Ngugi (Matigari 1989) illustrates that neocolonial leaders' incompetence has had a wide range of consequences. The middle class, particularly the youth, will bear the brunt of the results. Capitalism is indeed a capitalist system. The ruling elite's campaign is tough on all groups of society; additionally, the youth are being targeted as the inheritors of the two folds impact of future suffering: physically and mentally.

According to (Ogude, 1999), this is the more risky method, the guys' optimism was well-founded. Matigari's school has been damaged, and the students have been forced to reside in one of the scrapyards. Nairobi, Kenya (Wa Thiong'o 1986) characterizes these youngsters' predicament as a sacrifice due to poverty. The perplexing loss of their ancestral lands and their wishes for a prosperous life after Socioeconomic factors damage their ability to finish school, prompting them to become beggars and homeless. (Wa Thiong'o and Ngugi wa Mirri, 1982). In Kenya, the facts of colonial dominance and the neocolonial elites' atrocities are revealed. The Ngugi's Both are pushing for a "return to sources," as (Knight, 1983) defines it. All they want is for the situation to improve. The unequal distribution of wealth that initially belonged to Kenyans. As a result, Ngugi's assertion in Detained A Writer's Prison Diary that:

"Being aware of such cultural imperatives and actively participating in the struggle is the first step."

The emphasis of history in the passage of forces between the paradigms of being and being is the essence of being. Differences in politics, society, and economy" (p. 98).

According to (Balogun, 1995), literature regarding neocolonialism is an active tool in educating people. There is a split in the masses in regards to the fight against social, political, economic, and physiological injustices in African societies. He encourages African writers, in particular, to concentrate on their work, more on exposing African leaders' exploitation of people they share space with 
citizenship. (Ogude, 1999) elaborates on the concept of political dissent by praising Ngugi for his achievements. His response to the neocolonial elite's activities has resulted in a lack of faith in the system. The masses lead the elite. He also agrees with Ngugi's concerns regarding the fate of the orphans and the poor.

Ngugi's message of "rage and outrage against the ruling class should not be ignored" says the report. Misinterpreted as rebellious, but it should be viewed as a means of sparking a fire in the hearts of those who need it most. A smart ruling elite to recognize the value of societal acceptance" (Wa Thiong'o, 1999). Other authors (Ousmane, 1983); (La Guma, 1986); (Cook \& Okenimkpe, 1997); Ngugi's literary work does certainly capture the history (Sonyika, 1999); (Bhabha, 2005). And recollections of the past and, unfortunately, features of the elite's exploitation of the masses in Kenya are a neocolonial country. Ngugi's novel Enactment of Power is a critique of the capitalist system. The system, as well as its expressions as economic alienation, rules for the lower classes from the means the neocolonial capitalists' mode of production Apart from Ngugi, other writers such as (Sonyika, 1994), (Ogude, 1999), (Fanon, 1986), and (Uwasomba, 2006) argues that class separation is frequently replicated as an indication of social tension throughout history. The police chief pulls out a pistol and points it at Matigari, threatening to shoot him if he does not comply with the cops (Wa Thiong'o, 1989). Even though Matigari does not display symptoms of insolence by not following the police's instructions, he is threatened with a gun, indicating social friction in Nairobi's community and that people's confidence has eroded. Nyanza writes an open letter to the African Union heads of state, reminding them to keep their promises to the African people:

This is my call: Don't just promise development, deliver it, and make it happen now. Make real, concrete progress towards investment that reaches all Africans. Investments that prioritize rural people are the most neglected by the governments. Our biggest resource is our people.

To squander them is worse than wasteful. If we do not act now, by 2030 Africa will account for 80 per cent of the world's poor. Is this what we want to leave for future generations?

(Wa Thiong'o 2009, p. 14)

He closes by reminding African leaders that their people are tired of stereotypes and are ready to be led to the real Africa, which is full of possibilities, dignity, and opportunity to face and solve their problems without the need for outside help. For so long, Africans have been associated with this picture (Grant, 1985) and (Gugler, 2011). Long: "a hungry and forlorn continent, destitute and hungry, corrupt and subject to foreign powers" exploitations (Nyanze, 2014).

\section{Theoretical framework}

Because this is a research-focused solely on fictional literature, it is critical to identify specific theoretical frameworks that support the theme of symbolic figures. Ngugi's Marxist worldview has been depicted in a variety of ways, for example, in the novel Petals of Blood, which was intended to teach Kenyan society about exploitation and corruption. In light of this situation, it is critical for this study to apply literary theories that can aid in the creation of information that confronts the real world about what the characters in the novel reflect (Wa Thiong'o, 1977). Because the story depicts class conflict, class struggle, and the reinforcing of class distinctions, this study used Marxist and Postcolonial ideas. These theories employ standard fictional analysis methodologies to address issues about the social and political connotations of repressive literature, which are relevant to Ngugi's Petals of Blood.

\section{Postcolonial theory}

Bitterli (1989) defines postcolonial theory as a "approach to literary analysis that is concerned with literature, primarily written in English in historically colonized countries."

The idea investigates what happens when two competing cultures collide, one of which has power and considers itself superior to the other. Two conflicting cultures are observed in this study: the western 
civilization left behind by colonisers and Kenyan culture. When compared to Kenyan culture, the neocolonial elite's western culture is thought to be superior.

Ngugi expresses his longing for Ilmorog's original setting in Petals of Blood, before the history of colonialism changed it into a commercial region. Petals of Blood examines the past, how the Ilmorogians survived and uses the past to carve out a new method of creating and understanding the new reality in which they find themselves. This rationale is in line with the idea of Postcolonial theory, which states that the writer must bring the past into the present in order to change the audience's future. The Ilmorogians lament the days when everyone had enough land to live on and farm. In other words, the Ilmorog community does not appreciate the modern developments that have occurred in the area. As a result, the contribution of Postcolonial theory to this work is to provide a better understanding of how the masses' conditions are encapsulated and inferred inside the text (Zizek, 2010). Because the preoccupation with activities associated with colonialism continues in neocolonial Kenya, postcolonial theory becomes significant.

\section{The Marxist literary theory}

The Marxist literary theory is another theory used in this research. This theory examines social processes such as the working class and peasant struggle, internal political struggles, and the strategy, tactics, and organization of the struggle (Eagleton,1976). Ngugi, influenced by Marx, encourages the exploited to band together in order to achieve effective results and ensure that things satisfy their demands. When he says:

\footnotetext{
Humanity is in turn born from many hands working together, for as Gikuyu once said that a single finger cannot kill a mouse, a single log cannot make fire last through the night, a single man, however strong cannot build a bridge across a river and many hands can lift a weight however heavy. (Wa Thiong'o, 1982)
}

The quotation above qualifies Ngugi as a Marxist novelist, and features of Marxism were noted in the three novels examined in this study. In Petals of Blood, he encourages individuals to battle for themselves so that they can eat the fruits of their labor, rather than sweating for others so that they might get wealthy (Hobsbawm, 2011) and (Easterly, 1997). Karega embodies the spirit of battling for justice, vowing not to repeat what he has done in the past when he believed lies from crafty politicians. He tells Akinyi, the girl who has come to see him in prison, that they must maintain the spirit of comradeship alive until the capitalist system that exploits the lower class is overthrown.

\section{Research methodology}

This is a qualitative study. The issue's literary text and critical resources (print and internet) are evaluated, assessed, and interpreted using qualitative research criteria. To begin, a summary of the chosen book's analytical methodology is offered. Then, using the applied theoretical framework, pertinent passages from the novel are picked and grouped into sub-themes through critical reading. Grounded theory practice, ethnography, phenomenology, case study, and textual analysis are all data gathering methodologies used in qualitative research (Melakneh, 2008). Using textual analysis, this study investigates how characters are used as a representation of the act and other text.

\section{Results and discussions \\ Symbolic characters in Ngugi wa Thiong'o's Petals of Blood}

Abdullah, a former freedom warrior who lost a leg in the campaign for Kenyan independence, runs a duka, or shop, in Ilmorog, where he sells groceries and drinks to the locals. Abdullah, like the other characters, has come to Ilmorog to escape his previous life, its terrible memories, and its responsibilities. He had joined the Mau Mau revolt and fought in the forest with the charismatic leader Ole Masai, and he had been one of the bravest and most active participants in the campaign for independence. Abdullah has a noble character in him and good characters are based on morals (Hirshin, 2021). Kimeria had betrayed him and Karega's brother, Nding'uri, during the insurrection. Abdullah 
was able to flee, but Nding'uri was hanged. Abdullah returns to Limuru, his hometown, after independence, expecting to see the rewards of his struggle - the redemption of the land for the people.

Abdulla is both a symbol of bravery and a symbol of betrayal. He and his ilk battled for Kenya's independence from the constraints of colonialism and colonial brutality. Some of his associates, such as Ole Masai and Ndunguri, died as a result of the conflict. Their death could be compared as a freedom sacrifice. Abdulla, a symbol of bravery and the unsung hero of Kenya's independence, is also a guide and protector for the people of Ilmorog.

The image of Abdulla is highly important when it comes to the delineation of symbolic characters. Abdulla must be cited as a symbol of "betrayal" if any character can be. He represents the liberation battle for independence and social justice veterans. However, he and those he represents, unfortunately, become outsiders in the very community for which they made such great sacrifices. The force of Power and dehumanization tramp on and betray him, leaving him physically traumatized, deeply frustrated, and financially impoverished. When he needed money and moral support, he was completely powerless, but his courage was unquestionable. It's unsurprising that the hordes of half-naked toddlers with swollen tummies are claiming their respective claims among rotting garbage and trash "(137) he observes on his journey to face Kimeria fuels his desire to retaliate against society. Despite this, Abdulla appears to be unable to successfully tackle societal problems in the current situation.

Karega is a young man who used to work as a teaching assistant at Munira's school before getting disillusioned and moving to the city. Young people are the hope, strength, and agility of any given society (David, 2021). He becomes enamored with socialism during his trip to Nairobi and begins to educate himself on Nairobi's concepts and the laws. However, he later grows disillusioned with education's consequences and how useful it is in the quest for freedom.

Karega and Lawyer are revolutionaries, according to Ngugi, who sees them as freedom warriors who will help alter the system in their society. They call for a walkout to ensure that workplace inhumanity is no longer tolerated. Karega has passed through the mill and has firsthand knowledge and experience of society. As a result, he placed himself forward in confronting the objective truth of the current condition of affairs, raising important problems at the heart of societal disparities and contradictions. Karega's quest for answers to the many questions that preoccupy his mind about the world around him leads him to collide with the factors that cause inequity. He can make a connection between cause and consequence. Karega is described by Gikandi (2000) as "a character of praxis" for this reason. (139). Obviously, a Karega is required to set off the reforms. Karega* responds by positioning himself as a mediator, a social change agent, after realizing that he lives in "a world of grab and take... a society constructed on a framework of inequality and injustice... a world where some can eat while others can only toil" (240).

Nyakinyua's granddaughter Wanja. As a seasoned barmaid who is fleeing her city past. She falls in love with Karega, despite Munira's desire for her. She also sleeps with Abdulla due to her admiration for his role in the Mau Mau uprising. She is a hardworking barmaid who helps Abdulla's shop succeed while simultaneously selling Theng'eta. After being injured in Munira's arson attempt, she becomes a prostitute and runs her own brothel. Wanja's destruction by Kimeria is a reference to this fact. Wanja's expression reflects Kenya, and she is genuinely lovely. She was bright at school, and her teachers were optimistic about her future. She was essentially fecund, which explains why she is linked to the rain god.

Wanja's narrative isn't much better than Karega's. Wanja, like Karega, has a string of bad luck, owing in part to her proletarian upbringing. Wanja had to deal with her parents' continual feuds throughout her youth, making growing up difficult for her. Wanja drops out of school as a result of an adolescent pregnancy caused by her father's debauched, wealthy acquaintance. Wanja is forced to get rid of her baby due to the uncertainty of being a teenage mother, thereby absolving herself of parental responsibilities while also plunging herself into the world of prostitution. So, how does Wanja deal with her predicament, which was brought on by an indifferent society? Of course, Wanja's Sunshine Lodge, 
which stands alongside All Saints Church in New Ilmorog, is a means of retaliation against people who have denied her the right to live a normal life. As in the novel, Wanja is a symbol of prostitution.

Muruk's mother, Wambui, was stumbling behind the wheelbarrow, which was stacked high with stones. Many tillers and herders had been stripped of their previously unchallenged rights of usage and cultivation as a result of land demarcation and fencing. They were now renting themselves out to anyone in need of wage labor. Wambui, you're a laborer! She had now joined the ranks of others who had been pulled into Ilmorog's sweatshop for sweat and labor (272 - 73).

Muruiki becomes a symbol of corruption as he turns criminal and tries to plunder the African Economic Bank. The proletariat's abjection is most visibly shown in the filthy, worn-out Md shredded garments they wear. Images like these jar the reader's sensibilities and immediately convey the characters' difficulties and privations.

Munira's visit in Old Ilmorog serves to highlight the people's crushing poverty, as evidenced by youngsters who "were sometimes a disgusting sight," with "flies swarming around the stinging eyes and mucus blocked noses," and "most had just frayed calicoes for clothing" (24). Abdulla's son, Joseph, is a symbol of poverty. He is one of the children that wear rags as clothing; when he joined Abdulla, it appears that all he has are a shirt and shorts "torn at the seat." (30) " Poverty does not only affect youths; it also affects adults' physical appearance. Indeed, the majority of the labor-supplying classes are so impoverished that they can hardly afford to clothe themselves. They are generally clothed in outfits that aren't suitable.

Munira's bemoaning of the disheveled and torn appearance of the laborers in her father's job aptly illustrates this point. "Two of the laborers had been in his father's work long since Monira could remember," it says, "still wearing the same style of patched up trousers and nginyira for shoes." (14) In the narrative, Karega's parents are a metaphor for exploitation at its worst. Exploitation, whether perpetrated by Europeans or Kenyans, has a variety of effects on the proletariat. It could be physical, social, financial, or psychological. All of these factors combined in Karega's case result in his parents' divorce at two distinct times.

They (Karega's parents) had lived as squatters on different European farms provided free labour in return of some grazing and cultivation rights on the settler's lands. They would be given a piece of land in the bush. They would clear it and after a year they would be driven off and shown other virgin lands to clear for the European landlord. Thus they had move from one landlord to the next until they ended in Elburgon... it was at Elburgon that his father and mother quarreled. She complained about the triple duties... she was expected to work on European farms; to work on her own piece of land; and to keep the home... At the some time she never saw cent from her produce. Usually her husband would take it and sell it to the same European farmer., their landlord, who fixed his own buying price (57 - 8).

Karega's mother, Miriamu, revolted and divorced her husband, unable to tolerate the mistreatment. As a result, the economic exploitation of the proletariat contributes to family discord and conflict. It's worth noting that Karega's birth occurred during a time when his parents' relationship was tumultuous and chaotic.

Karega, who was born in extremely difficult circumstances, goes through similar situations in his later years. Karega, like his father, moves from odd job to odd job, exploitation to exploitation, "- moving, working here there, on this or that farm." (239) At one point, he and his co-workers "loaded the ships... 
handled all that wealth" while "sweating shirtless in the humid sun." (288) When he finds a job on a plantation, he realizes that laborers are no better than slaves, which he charges. In other situations, an entire family is forced to work as slaves, with "their entire family labor... man, woman, and children... living in one hut sentenced to picking sisal and tea - leaves and coffee." (288) We also observe a sugar milling corporation that is in the process of developing and enhancing people's standards of living exploiting and further impoverishing the poor through Karega's eyes:

number of peasants were driven off their land to make room for the company's nuclear estates.

The peasants who were not driven off the land were encouraged to grow sugar on their plots instead of food. But the company buys the sugar at whatever price they deem fit $^{5} . .$. so they lead miserable lives. Some cannot even send their children to school... (289)

Exploitation and poverty appear to be the proletariat's lot in life. They are denied almost everything, from food to shelter and clothing, because they are exploited. And capitalism, as shown in the novel, assures that the "interminable cycle of destruction and deprivation amidst plenty" (317) is maintained to the bourgeoisie's delight and gain, but to the proletariat's absolute detriment. Indeed, most of Ngugi's narrative is devoted to addressing the perplexing subject of class inequality. For example, Karega's desire to solve the thorny problem led him to pose one of the novel's most crucial questions: "How did it come to be that $75 \%$ of those who produce food and wealth are destitute, while a small minority - part of the non-producing population - is wealthy... How come that parasite... who did no constructive labor lived in luxury while those who toiled twenty-four hours a day were hungry and barefoot? (p. 198-9) Without a doubt, this is the crux of the matter, and it has a significant impact on the symbolic nature of the proletariat.

The rich and the poor, the haves and have-nots, the bourgeois comprador class, and the downtrodden proletariat class divide the society that sharpens Ngugi's revolutionary vision. The fundamental social reality is inequality between the two classes. Munira, Karega, Abdulla, and Wanja's mind is pervaded by this social reality. These symbolic characters join forces with rural peasants led by Njakinyua to fight the status quo, which is embodied by Chui, Mzigo, Ezekiel Waweni, Rev. Jerrod Brown, and Nderi wa Riera, based on their personal experiences and understanding of the workings of society.

\section{Conclusion}

In conclusion, Ngugi's literary work stands as a beacon of hope for the construction of a better Society, Kenya and provides future generations with a desire to establish better environments with equal opportunities, and no segregation between them. The study, symbolic characters, and class struggle can open up many opportunities for literary studies because it is an intricate subject that deserves specific attention in our time when most countries are experiencing upheavals.

\section{Limitation/recommendation}

The study is limited to one novel of Ngugi written after the post-independence of Kenya. Another constraint is that some of Ngugi wa Thiong'o's novels written in Gikuyu have not been used in this study because the researcher does not understand the language used in writing them, even though they may contain relevant information on class struggles and symbolic characters during the textual analysis. In order to end the class struggle, the study advocates for reforms in Kenya that would be ideal for all the classes of people by extension Africa.

The study recommends revolution whenever the leaders refused to do the needful that will benefit the masses.

\section{Acknowledgment}

There was no financial support from anybody in carrying out this research. 


\section{References}

Achebe, C. (1985). Things fall Apart. Harare, Zimbabwe: Zimbabwe Publishing House. Love story.Oxford University Press.

Aidoo, K. (2007). A love story. Oxford University Press.

Amuta, C. (1986). Towards a sociology in African literature. Zim Pan-African Publishers.

Amuta, C. (1989). The theory of African literature: Implications for practical criticism. Atlantic Highlands Press.

Amuzu. K. (2004). Beyond ideology: Literary technique in Ngugi's Petals of blood and Devil on the cross.Minerva Press.

Balogun, O.F (1995). Ngugi's Devil on the Cross: The novel as hagiography of a Marxist. Ufahamu, $16,76-92$.

Bardolphe, J. (1987). Ngugi wa Thiong'o's Grain of Wheat and Petals of Blood: As readings of Conrad's Under Western eyes and Victory. The Canadian, 12, 32-49.

Bhabha, H. (2005). "Foreword: Framing Fanon." The wreched of the earth. Groove Publishing

Bitterli, U. (1989). Cultures in conflict: Encounters between European and non-European, 1492-1800. Polit: Oxford University Press.

Cook, D. \& Okenimkpe, D. (1997). Ngugi wa Thiong'o: An exploration of his writings. James Currey

David, M. (2021). Relevance of Youth Representation through Political Proportion in Uganda. Journal of Governance and Accountablity Studies (1)1 29-41.

Eagleton, T. (1976). Marxism and literary critism. Berkeley. University of Califonia Press.

Eagleton, T. (2013). Why Marx was right. Yale University Press.

Easterly, W. (1997). Africa's growth tragedy: Politics and ethnic divisions. Quarterly Journal of Economics, 112, 1203-1250.

Fanon, F. (1986). Black skin, white masks. Pluto.

Fanon, F. (Ed.). (1990). The wretched of the earth. Harmondsworth: Penguin.

Fashina, N. O. (2009). Alienation and revolutionary vision in East African post-colonial dramatic literature. Ufahamu: A Journal of African Studies, 2(35). Retrivieved on 12 July 2013, from http/www. Escacholarship.org/uc/item/63k8d46k on July 8, 2015.

Gikandi, S. (2000). Ngugi wa Thiong'o.: Cambridge University Press

Godson, K. (2021). Leadership Styles and Employees' Performance: A case of Family-owned Manufacturing Company, Cape Cost. International Journal of Financial, Accounting, and Management, 3(2) 149-164.

Grant, K. (1985). Marxism and African Literature.George M. Gugelberger Press.

Gugler, J. (2011). How Ngugi wa Thiong'o shifted from class analysis to a neo-colonialist perspective. The Journal of Modern African Studies, 32(2), 329-339

Herbst, J. (2000). States and power in Africa: Comparative lessons in authority and control. Princeton University Press.

Hirshin, A (2021). Globalization, Islam Nusantra, and Contemporary Character empowerment Journal of Social, Humanity, and Education, 1(2) 79-89.

Hobsbawm, E. (2011). How to change the world. Marx and Marxism 1840-2011. Little, Brown.

Killam, G.D (Ed.). (1984). Critical perspectives on Ngugi. Heinemann.

Killam, G.D (Ed.). (1980). An introduction to the writings of Ngugi.: Heinemann.

Knight, E. (1983). "Mirror of reality: The novels of Mwangi." African Literature Today, 13, 150.

Kubayanda, J. (2013). Dictatorship, oppression and new realism. Research in African Literatures, 21(2) $5-12$

Kurtz, R. (1998). Urban obsessions urban fears: Postcolonial Kenyan novels. Oxford, UK.

La Guma, (1986). The stone country. Heinemann. James Currey

Mahammad, R, and Seyed, A. (2021). Examining the Quality of Work Life: empirical testing Indicator in the Public Organization. Journal of Annals of Human Resource Management Research, 1(2) 99-111.

Matigari, M. (1989). The centre cannot hold: Two views of the periphery. In Slemon, S. \& H.

Melakneh, P. G. (2008). Qualitative evaluation and research methods. SAGE Publications.

Mushengezi, A. (2003). Twentieth century literary theory. Mukono Bookshop Printing and Publishing Co. Ltd.

Mwaura, N. (2005). Kenya today: Breaking the yoke of colonialism in Africa. Algoa. 
Nyanze, K. (2014). An open letter to African Union heads of state. New Era, p.14

Ogude, J. (1999). Ngugi's novel and the African history: Narrating the nation. Pluto Press

Ousmane, S. (1983). Last of the empire. Heinemann.

Sonyika, W. (1994). The open score of a continent. Vintage Books.

Sonyika, W. (1999). From ghetto to Garrison: A chronic case of Orisunitis. Research in African Literatures, 30(4), 19-23

Uwasomba, C. (2006). The politics of resistance and liberation in Ngugi wa Thiong'o's Petals of Blood and Devil on the cross. The Journal of Pan African Studies, 6(1), 94-105

Wa Thiong'o, N. (1977). Petals of Blood E.P Dutton.

Wa Thiong'o, N. (1982). Barrel of a pen: Resistance to repression in neo-colonial Kenya. African World Press.

Wa Thiong'o, N. (2009). Something torn and new: An African renaissance.Basic Civitas Books.

Wa Thiong'o, N. (1986b). Writing against neo-colonialism. Wembley.Vita Books.

Wa Thiong'o, N. \& Wa Mirri, N. (1982b). I will Marry When I Want. Heinemann

African Writers

Wa Thiong'o, N. (1989). Matigari. Heinemann International books.

Wa Thiong'o, N. (1999). Penpoints, gunpoints and dreams: Towards a critical theory of the arts and the state in Africa. Oxford University Press.

Zizek, S. (2010). Living in the end times. Verso Publishing 